\title{
Role of Surgery in the Treatment of Radiation-Induced Sarcomas of the Head and Neck
}

\section{Gregory SK Lau*, Jimmy YW Chan and William I Wei}

Department of Surgery, University of Hong Kong, Queen Mary Hospital, Hong Kong

\begin{abstract}
Introduction: Radiation-induced sarcoma (RIS) is a well-known complication of radiotherapy. It is an aggressive tumour and the prognosis is often poor, despite radical treatment. We aim to investigate the role of surgery in the treatment of patients with RIS of the head and neck region.

Method: We conducted a retrospective review of records of patients whom were treated for radiation-induced sarcoma at Queen Mary Hospital, Hong Kong, between the period 1999 to 2010. Data collected included patient age, gender, latency period for the development of RIS, site of RIS, symptoms, treatment given, pathology and survival.

Results: Nineteen patients were included, $(M=11, F=8)$. Eighteen received radiotherapy for treatment of primary nasopharyngeal carcinoma. One received radiotherapy for carcinoma of the parotid. The medial latency period for the development of sarcoma was 11.1 years (range 5.3-25.1). The most common site for development of RIS was the neck $(n=8)$, followed by the oropharynx/oral cavity $(n=4)$, nasopharynx $(n=3)$ nasal cavity $(n=2)$, maxilla $(n=1)$ and mandible $(n=1)$. The most common histology was undifferentiated sarcoma $(n=6)$. Nine patients underwent surgical resection of the RIS with curative intent, three and six patients achieved R0 and R1 resection respectively. Chemotherapy was used in eleven instances after surgery. Radiotherapy was used in seven instances, three through brachytherapy, four through external beam irradiation. Overall medial survival from diagnosis of RIS was 1.74 years $(95 \% \mathrm{Cl} 0.60-2.87)$, which improves to 2.47 years $(95 \% \mathrm{Cl} 0.97-3.97)$ when only calculating those whom surgery was performed.

Conclusions: Patients suffering from radiation-induced sarcomas have a poor prognosis, in keeping with existing literature. Treatment is mainly by surgery aiming at resection with a curative intent. If curative resection is impossible, surgery may still have a role in palliating the patients' symptoms such as bleeding, fungation, or pain.
\end{abstract}

\begin{abstract}
Abbreviations: WLE: Wide local excision; DP flap: Deltopectoral flap; ALT flap: Anterolateral thigh flap

\section{Introduction}

Radiation-incuded sarcoma (RIS) is a well known complication following radiation therapy. The incidence of radiation-induced sarcoma in the head and neck region is rare. The incidence of RIS in post-irradiated bone is reported to be in the range of $0.03 \%$ to $0.8 \%$ [15]. There are also large variations in reported latency period between completion of radiotherapy to the development of the sarcoma. This can be as short as three years and as long as five decades [5-7].

Treatment of radiation-induced sarcomas may include surgical resection, chemotherapy, further irradiation (external beam or brachytherapy), or a combination of the above. However, treatment of these tumours in the head and neck region, causes great morbidity to the patient as vital functional organs may need to be sacrificed and the patient is left disfigured.
\end{abstract}

Current literature reports a poor prognosis for patients with postirradiation sarcoma. Wei-wei et al. [4] reported $60 \%$ and $24 \%$ for one and two year survival respectively in a group of patients developing osteosarcoma after radiotherapy for nasopharyngeal carcinoma. The role of surgery in the treatment of patients with radiation-induced sarcoma is still unclear.

\section{Method}

A retrospective review was performed on patients diagnosed to have radiation-induced sarcoma in the head and neck region, over a period 1999-2010. The patients were treated at Queen Mary Hospital, a tertiary referral centre and also university teaching hospital in Hong
Kong. Patients included were those fulfilling the diagnostic criteria set out by Cahan in 1948 [8]: 1) The sarcoma arises in an irradiated area, 2) There is a relatively long asymptomatic period, 3) There is histological proof of the sarcoma and 4) The sarcoma is histologically distinct from the original condition. Primary sarcomas arising de novo in the head and neck region were excluded.

Data collected included age, gender, latency period from completion of radiotherapy to development of sarcoma, site of sarcoma, symptoms, histology of sarcoma, treatment given, pathology and the survival period.

Statistical analysis was performed using the SPSS package v16.0 (Table 1).

\section{Results}

\section{Patient demographics}

A total of 19 patients fitting the criteria were included, eleven male and eight female. Eighteen of the patients received radiotherapy

${ }^{*}$ Corresponding author: Gregory SK Lau, Department of Surgery, Queen Mary Hospital, University of Hong Kong, Hong Kong, E-mail: lau.greg@gmail.com

Received November 13, 2011; Accepted December 13, 2011; Published December 15, 2011

Citation: Lau GSK, Chan JYW, Wei WI (2011) Role of Surgery in the Treatment of Radiation-Induced Sarcomas of the Head and Neck. J Cell Sci Ther S2:002. doi:10.4172/2157-7013.S2-002

Copyright: @ 2011 Lau GSK, et al. This is an open-access article distributed unde the terms of the Creative Commons Attribution License, which permits unrestricted use, distribution, and reproduction in any medium, provided the original author and source are credited. 
Page 2 of 4

for nasopharyngeal carcinoma. The remaining patient received radiotherapy for carcinoma of the parotid gland. The median age was 51 years old (range 36-83). The median latency period from the last radiotherapy to presentation of sarcoma was 11.1 years (range 5.3-25.1 years).

\section{Treatment}

Of the 19 patients, nine (47\%) received surgical resection with curative intent. Eight patients (42\%) received palliative treatment, including four having non-surgical treatment because of unresectable disease and four having palliative surgery. Of those having palliative surgery, two had debulking surgery and the remaining two had macroscopic tumour left behind intraoperatively (Table 2). There were a total of thirteen surgeries. One patient refused surgery and another one died of unrelated causes. None of the patients presented with distant metastases.

The surgeries performed included radical neck dissection $(\mathrm{n}=5)$, maxillectomy $(\mathrm{n}=3)$, maxillary swing nasopharyngectomy $(\mathrm{n}=1)$, mandibulectomy $(\mathrm{n}=1)$, endoscopic assisted cranionasal resection $(n=1)$, debulking surgery $(n=2)$. Nine patients required flap reconstruction of the resulting defect. These included the fasciocutaneous deltopectoral flap $(n=3)$, free anterolateral thigh flap $(n=3)$, pectoralis major myocutaneous flap $(n=2)$, and free fibular osteocutaneous flap $(n=1)$. Two patients developed local recurrence of the sarcoma which further wide local excision and reconstruction was performed. The operations performed are detailed in Table 3.

Chemotherapy was used in eleven instances, which eight of them were of palliative intent. Radiotherapy was used in seven instances, three through brachytherapy, four through external beam irradiation. Three of the four patients receiving external beam radiotherapy were of palliative intent.

\section{Tumour clearance}

Nine of the thirteen patients receiving resection achieved macroscopic tumour clearance. Six of these nine patients were found

\begin{tabular}{|l|c|c|}
\hline \multicolumn{1}{|c|}{$\mathrm{n}=19$} & Proportion \\
\hline Latency Period & & \\
\hline$>20$ years & 3 & $16 \%$ \\
\hline $10-20$ years & 5 & $58 \%$ \\
\hline $5-9$ years & 0 & $26 \%$ \\
\hline $1-4$ years & & $0 \%$ \\
\hline Site & 8 & \\
\hline Neck & 4 & $42 \%$ \\
\hline Oropharynx / Oral cavity & 3 & $21 \%$ \\
\hline Nasopharynx & 2 & $16 \%$ \\
\hline Nasal Cavity & 1 & $11 \%$ \\
\hline Maxilla & 1 & $5.3 \%$ \\
\hline Mandible & & $5.3 \%$ \\
\hline Histology & 6 & \\
\hline Undifferentiated & 4 & $32 \%$ \\
\hline Osteosarcoma & 4 & $21 \%$ \\
\hline Rhabdomyosarcoma & 2 & $21 \%$ \\
\hline Pleomorphic sarcoma & 1 & $11 \%$ \\
\hline Angiosarcoma & 1 & $5.3 \%$ \\
\hline Leiomyosarcoma & 1 & $5.3 \%$ \\
\hline Malignant fibrohistiosarcoma & & $5.3 \%$ \\
\hline & & \\
\hline
\end{tabular}

Table 1: Tumour characteristics.

\begin{tabular}{|l|c|c|}
\hline Treatment & 13 & $68 \%$ \\
\hline Surgical resection & 4 & $21 \%$ \\
\hline R2 Resection & 6 & $32 \%$ \\
\hline R1 Resection & 3 & $16 \%$ \\
\hline R0 Resection & 1 & \\
\hline & 3 & $*$ \\
\hline Adjuvant External RT & 3 & $*$ \\
\hline Palliative External RT & 3 & $*$ \\
\hline Brachytherapy & 8 & $*$ \\
\hline Adjuvant chemotherapy & & \\
\hline Palliative chemotherapy & 10 & $53 \%$ \\
\hline & 2 & $11 \%$ \\
\hline Outcome & 2 & $11 \%$ \\
\hline $\begin{array}{l}\text { Died of disease (inclusive of local disease } \\
\text { progression, local recurrence, } \\
\text { distant metastasis) }\end{array}$ & 3 & $16 \%$ \\
\hline Died of complications of chemotherapy & 2 & $11 \%$ \\
\hline Died of unrelated causes & & \\
\hline Alive without disease & * & \\
\hline Alive with local recurrence & & \\
\hline
\end{tabular}

* Percentages not calculated as these numbers indicated occurrences of each therapeutic method.

Table 2: Treatment and outcome of patients.

to have microscopically involved resection margins. Three patients achieved R0 clearance.

\section{Histology}

The most common histological type of radiation-induced sarcoma was of the undifferentiated type $(n=6)$. This was followed by osteosarcoma and rhabdomyosarcoma ( $\mathrm{n}=4$ each), pleomorphic sarcoma $(\mathrm{n}=2)$, angiosarcoma $(\mathrm{n}=1)$, leiomyosarcoma $(\mathrm{n}=1)$ and malignant fibrohistiosarcoma $(\mathrm{n}=1)$.

\section{Local recurrence and distant metastasis}

Two patients who initially had R0 resection of the neck tumour developed local recurrence, necessitating further wide resection. These two patients currently have no evidence of tumour recurrence. Two patients, who initially achieved R1 resection, later developed lung metastasis without local recurrence and subsequently passed away. Two patients recently developed to have local recurrences at the time of analysis pending further workup and treatment.

\section{Survival}

Overall median survival from diagnosis of sarcoma was 1.74 years (95\% CI 0.60-2.87). For the thirteen patients who underwent surgical resection, the median survival was 2.47 years (95\% CI 0.97-3.97). For those who had no surgery, median survival was 0.82 years $(95 \%$ CI 0.35-1.29).

\section{Symptoms and morbidities}

Five patients (26\%) complained of recurrent tumour bleeding and fungation.One patient them died from a carotid blow-out secondary to direct tumour invasion. Four patients had good palliation of symptoms of bleeding and fungation after the tumour was surgically resected with flap coverage, even though clear margins could not be achieved. Three patients (16\%) had intractable pain despite analgesics. In one patient the tumour invading into the brachial plexus was excised macroscopically for palliation, followed by flap coverage and brachytherapy. There was good palliation of her pain for more than 
Citation: Lau GSK, Chan JYW, Wei WI (2011) Role of Surgery in the Treatment of Radiation-Induced Sarcomas of the Head and Neck. J Cell Sci Ther S2:002. doi:10.4172/2157-7013.S2-002

Page 3 of 4

\begin{tabular}{|c|c|c|c|c|c|c|c|c|c|c|}
\hline$\#$ & Sex & Age & $\begin{array}{l}\text { Latency } \\
\text { Period } \\
\text { (years) }\end{array}$ & $\begin{array}{c}\text { Size and Site of } \\
\text { Tumour }\end{array}$ & Operation & $\begin{array}{l}\text { Recon- } \\
\text { struction }\end{array}$ & Clearance & $\begin{array}{c}\text { Chemotherapy I } \\
\text { Radiotherapy }\end{array}$ & $\begin{array}{c}\text { Outcome } \\
\text { (at time of analysis) }\end{array}$ & $\begin{array}{c}\text { Survival from } \\
\text { diagnosis } \\
\text { (Years) }\end{array}$ \\
\hline 1 & $\mathrm{~F}$ & 46 & 10.0 & Right neck & Debulking & DP Flap & $\mathrm{R} 2$ & $\begin{array}{l}\text { Brachytherapy } \\
\text { and } \\
\text { palliative } \\
\text { chemotherapy }\end{array}$ & $\begin{array}{c}\text { Disease progression, } \\
\text { died }\end{array}$ & 5.42 \\
\hline 2 & $\mathrm{~F}$ & 40 & 9.8 & Left nasopharynx & (Unresectable) & - & - & $\begin{array}{c}\text { Palliative } \\
\text { chemotherapy }\end{array}$ & $\begin{array}{c}\text { Disease progression, } \\
\text { died }\end{array}$ & 0.83 \\
\hline 3 & M & 56 & 20.0 & $\begin{array}{l}\text { 1) Left neck } \\
\text { 2) Local recurrence } \\
\text { (5 years interval) }\end{array}$ & $\begin{array}{l}\text { 1) RND } \\
\text { 2) Wide local excision, } \\
\text { manubrial resection }\end{array}$ & $\begin{array}{l}\text { 1) DP Flap } \\
\text { 2) PM Flap }\end{array}$ & $\begin{array}{l}\text { 1) } R 0 \\
\text { 2) } R 0\end{array}$ & 2) Brachytherapy & Alive without disease & Alive \\
\hline 4 & $\mathrm{~F}$ & 49 & 18.2 & Left nasal cavity & $\begin{array}{c}\text { Endoscopic cranionasal } \\
\text { resection }\end{array}$ & - & $\mathrm{R} 1$ & $\begin{array}{c}\text { Palliative } \\
\text { chemotherapy }\end{array}$ & Local recurrence, died & 2.5 \\
\hline 5 & $\mathrm{~F}$ & 48 & 23.3 & $\begin{array}{l}\text { Right upper } \\
\text { alveolus }\end{array}$ & (Refused) & - & - & - & $\begin{array}{c}\text { Disease progression, } \\
\text { died }\end{array}$ & 1.92 \\
\hline 6 & M & 36 & 11.0 & Nasopharynx & $\begin{array}{c}\text { Maxillary swing } \\
\text { nasopharyngectomy }\end{array}$ & - & $\mathrm{R} 2$ & $\begin{array}{c}\text { Palliative } \\
\text { chemotherapy }\end{array}$ & $\begin{array}{l}\text { Died of chemotherapy } \\
\text { complication }\end{array}$ & 0.42 \\
\hline 7 & $\mathrm{~F}$ & 64 & 25.2 & Right oropharynx & (Unresectable) & - & - & $\begin{array}{c}\text { Palliative } \\
\text { chemotherapy }\end{array}$ & $\begin{array}{c}\text { Disease progression, } \\
\text { died }\end{array}$ & 1.75 \\
\hline 8 & $\mathrm{~F}$ & 52 & 5.3 & Right nasal cavity & Endoscopic debulking & & $\mathrm{R} 2$ & $\begin{array}{c}\text { Palliative } \\
\text { chemotherapy }\end{array}$ & $\begin{array}{l}\text { Died of chemotherapy } \\
\text { complication }\end{array}$ & 0.92 \\
\hline 9 & M & 48 & 9.3 & Right mandible & $\begin{array}{c}\text { Segmental } \\
\text { mandibulectomy }\end{array}$ & $\begin{array}{c}\text { Reconstruction } \\
\text { plate + PM } \\
\text { Flap }\end{array}$ & $\mathrm{R} 1$ & - & Lung metastases, died & 1.58 \\
\hline 10 & M & 48 & 22.3 & Left maxilla & Maxillectomy & ALT flap & $\mathrm{R} 2$ & $\begin{array}{c}\text { Palliative } \\
\text { chemoirradiation }\end{array}$ & $\begin{array}{c}\text { Disease progression, } \\
\text { died }\end{array}$ & 1.83 \\
\hline 11 & $\mathrm{~F}$ & 83 & 20.0 & Right neck & Nil & - & - & - & $\begin{array}{l}\text { Died of unrelated } \\
\text { cause }\end{array}$ & 0.25 \\
\hline 12 & M & 55 & 10.3 & Left neck & RND & - & Ro & - & Alive without disease & Alive \\
\hline 13 & M & 51 & 10.2 & Right neck & RND & PM Flap & $\mathrm{R} 1$ & - & $\begin{array}{l}\text { Died of unrelated } \\
\text { cause }\end{array}$ & 0.92 \\
\hline 14 & $\mathrm{~F}$ & 55 & 7.0 & $\begin{array}{l}\text { 1) Right neck } \\
\text { 2) Local recurrence } \\
\text { (1 year interval) }\end{array}$ & $\begin{array}{c}\text { 1) RND } \\
\text { 2) Wide local excision }\end{array}$ & 2) PM Flap & Ro & $\begin{array}{c}\text { 1) Adjuvant } \\
\text { chemotherapy } \\
\text { 2) Brachytherapy }\end{array}$ & Alive without disease & Alive \\
\hline 15 & M & 54 & 12.2 & Right neck & (Unresectable) & - & - & $\begin{array}{c}\text { Palliative } \\
\text { chemotherapy } \\
\text { and haemostatic } \\
\text { RT }\end{array}$ & $\begin{array}{c}\text { Disease progression, } \\
\text { died }\end{array}$ & 0.75 \\
\hline 16 & $M$ & 69 & 7.7 & Right neck & RND & DP Flap & $\mathrm{R} 1$ & - & Lung metastases, died & 0.75 \\
\hline 17 & M & 47 & 11.2 & Nasopharynx & (Unresectable) & - & - & Haemostatic RT & $\begin{array}{l}\text { Disease progression, } \\
\text { died }\end{array}$ & 0.75 \\
\hline 18 & M & 47 & 12.3 & Oral cavity & Maxillectomy & ALT flap & $\mathrm{R} 1$ & $\begin{array}{c}\text { Adjuvant } \\
\text { chemotherapy }\end{array}$ & Local recurrence & Alive \\
\hline 19 & M & 63 & 15.0 & $\begin{array}{l}\text { 1) Alveolus } \\
\text { 2) Skull base } \\
\text { recurrence }\end{array}$ & $\begin{array}{l}\text { 1) Maxillectomy } \\
\text { 2) Craniofacial resection }\end{array}$ & ALT flap & $\begin{array}{l}\text { 1) } R 1 \\
\text { 2) } R 1\end{array}$ & $\begin{array}{l}\text { 1) Adjuvant RT } \\
\text { 2) Adjuvant } \\
\text { chemotherapy }\end{array}$ & Local recurrence & Alive \\
\hline
\end{tabular}

Table 3: Detailed information on patients' presenting symptoms, treatment offered, outcome and survival.

a year before the sarcoma rapidly recurred. Four patients (21\%) had symptoms of dysphagia and/or aspiration and required nutrition via a nasogastric tube. Two patients (11\%) had airway problems requiring a tracheostomy. Two patients (11\%) died of neutropenic sepsis during the course of chemotherapy.

\section{Discussion}

Radiation-induced sarcoma of the head and neck region, although a well known complication of the treatment itself, remains a rare diagnosis of poor prognosis $[9,10]$. The incidence of RIS increased with patient's age $[2,11]$. Survival of these patients is much poorer than patients having sarcoma of the extremities [3,12]. The reported overall 5-year survival is in the range of $10-30 \%$ [3,13-15]. In our group of patients, the median latency period of 11.1 years is comparable to the current available literature. This highlights the need for lifelong follow-up and surveillance of the cancer patient for any ill-effects from previous treatment, even when the patient is disease free from the primary tumour.

In our series eight patients received palliative treatment, which is $42 \%$ of the series. This is possibly the result of an aggressive tumour located in a body region that contains numerous vital structures and functional organs. Reasons for adopting palliative treatment might be due to encasement of major vessels such as the internal carotid artery, tumour too locally extensive at presentation. Where the patient was initially treated at a regional hospital, lack of expertise and awareness in reconstructive surgery options might lead to premature surrender to medical futility. Patients may also refuse surgery out of concern of significant facial disfigurement after radical surgery in the head and neck region. 
Citation: Lau GSK, Chan JYW, Wei WI (2011) Role of Surgery in the Treatment of Radiation-Induced Sarcomas of the Head and Neck. J Cell Sci Ther S2:002. doi:10.4172/2157-7013.S2-002

Nine patients out of the thirteen undergoing surgery $(69 \%)$ in our series received flap reconstruction of the resulting defect after tumour resection. When the radiation-induced sarcoma arises in the neck, we have a low threshold to excise the overlying skin together with the tumour so as to achieve better margins. When brachytherapy is contemplated, coverage preferably is performed using a reliable and robust flap such as the pectoralis major myocutaneous flap containing a good bulk of muscle to protect the carotid artery. This theoretically reduces the chance of carotid blow-out as the artery is likely to be laid bare after surgery. Reconstruction of other portions of the facial soft and bony tissues would follow existing reconstructive principles.

Chemotherapy is often applied to patients after surgical resection. Literature on usage of chemotherapy in radiation-induced sarcomas has been limited, and most reports spawn from treatment of primary sarcoma, especially osteogenic sarcoma in children and adults $[12,16]$. It is uncertain whether these regimens can be directly applied to radiation-induced sarcomas of the head and neck region and no large scale studies have been performed. Moreover, chemotherapy is not without its own complications. Two of our died from neutropenic sepsis while on chemotherapy.

The median survival was 2.47 years and 0.82 years respectively in those who had surgical resection versus those who had not. Given our small sample size, survival curve generation and further statistical testing was not performed. Our data seems to show that in a highly selected group of patients where R0 or R1 resection can be achieved, there may be a survival benefit. Further studies should be undertaken to clarify this.. In those patients where surgery was not curative, achieving gross tumour clearance may allow the patient to be palliated of symptoms of tumour bleeding, fungation and pain.

Of the three patients achieving R0 resection, two eventually developed local recurrences. This highlights the dilemma in treating radiation-induced sarcomas in the head and neck region where good margins are difficult if not impossible. Patients after treatment must also be followed-up regularly to pick up local recurrences promptly. It was fortunate that in both these cases, the recurrence was picked up early such that a second R0 resection could be made. Nevertheless, one patient required manubrial resection to achieve this.

\section{Conclusions}

Patients suffering from radiation-induced sarcomas have a poor prognosis, in keeping with existing literature. The role of surgery is to resect with a curative intent when possible. If curative resection is impossible, surgery may still have a role in palliating the patients' symptoms such as bleeding, fungation, or pain.

\section{References}

1. Tountas AA, Fornasier VL, Harwood AR, Leung PM (2005) Postirradiation sarcoma of bone: a perspective. Cancer 43: 182-187.

2. Huvos AG, Woodard HQ, Cahan WG, Higinbotham NL, Stewart FW, et al. (1985) Postradiation osteogenic sarcoma of bone and soft tissues. A clinicopathologic study of 66 patients. Cancer 55: 1244-1255.

3. Mark RJ, Poen J, Tran LM, Fu YS, Selch MT, et al. (1994) Postirradiation sarcomas. A single-institution study and review of the literature. Cancer 73: 2653-2662.

4. Wei-wei L, Qu-liang W, Guo-hao W, Zhi-hua C, Zong-yuan Z (2005) Clinicopathologic features, treatment, and prognosis of postirradiation osteosarcoma in patients with nasopharyngeal cancer. Laryngoscope 115: 1574-1579.

5. Huber GF, Matthews TW, Dort JC (2007) Radiation-induced soft tissue sarcomas of the head and neck. J Otolaryngol 36: 93-97.

This article was originally published in a special issue, Radiotherapy handled by Editor(s). Dr. V Krishnan Ramanujan, Cedars-Sinai Medical Center, USA
6. Mark RJ, Bailet JW, Poen J, Tran LM, Calcaterra TC, et al. (1993) Postirradiation sarcoma of the head and neck. Cancer 72: 887-893.

7. Murray EM, Werner D, Greeff EA, Taylor DA (1999) Postradiation sarcomas: 20 cases and a literature review. Int J Radiat Oncol Biol Phys 45: 951-961.

8. Cahan WG, Woodard HQ (1948) Sarcoma arising in irradiated bone; report of 11 cases. Cancer 1: 3-29.

9. Sale K, Wallace D, Girod D, Tsue T (2004) Radiation-induced malignancy of the head and neck. Otolaryngol Head Neck Surg 131: 643-645.

10. Pfeiffer J, Boedeker CC, Ridder GJ, Maier W, Kayser G (2006) Radiationinduced leiomyosarcoma of the oropharynx. Diagn Pathol 1:22.

11. King AD, Ahuja AT, Teo P, Tse GM, Kew J (2000) Radiation induced sarcomas of the head and neck following radiotherapy for nasopharyngeal carcinoma. Clin Radiol 55: 684-689.

12. Pellitteri PK, Ferlito A, Bradley PJ, Shaha AR, Rinaldo A (2003) Management of sarcomas of the head and neck in adults. Oral Oncol 39: 2-12.

13. Tabone MD, Terrier $P$, Pacquement $H$, Brunat-Mentigny $M$, Schmitt $C$, et al. (1999) Outcome of radiation-related osteosarcoma after treatment of childhood and adolescent cancer: a study of 23 cases. J Clin Oncol 17: 2789-2795.

14. Franco Gutiérrez V, Llorente Pendás JL, Coca Pelaz A, Cabanillas Farpón R, Suárez Nieto C (2008) Radiation-induced sarcomas of the head and neck. J Craniofac Surg 19: 1287-1291.

15. Brady MS, Gaynor JJ, Brennan MF (1992) Radiation-associated sarcoma of bone and soft tissue. Arch Surg 127: 1379-1385.

16. Bramwell VH, Burgers $M$, Sneath $R$, Souhami $R$, van Oosterom AT, et al (1992) A comparison of two short intensive adjuvant chemotherapy regimens in operable osteosarcoma of limbs in children and young adults: the first study of the European Osteosarcoma Intergroup. J Clin Oncol 10: 1579-1591.

\section{Submit your next manuscript and get advantages of OMICS Group submissions}

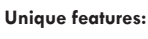

- User friendly/feasible website-translation of your paper

er to 50 world's leading languages

Audio Version of published paper

Digital articles to share and explore

Special features:

200 Open Access Journals

15,000 editorial team

21 days rapid review process

Quality and quick editorial, review and publication processing

Indexing at PubMed (partial), Scopus, DOAJ, EBSCO, Index Copernicus and Google Scholar etc

Sharing Option: Social Networking Enabled

Authors, Reviewers and Editors rewarded with online Scientific Credits

Better discount for your subsequent articles

Submit your manuscript at: http://www.editorialmanager.com/lifesciences 